\title{
Role of Research-based Learning on Graduates' Career Prospects
}

\author{
Adobi Jessica Timiyo ${ }^{1} \&$ Neelima Sriram ${ }^{2}$ \\ ${ }^{1}$ College of business, The American University of Malta, Bormla BML1013, Malta \\ ${ }^{2}$ Stella Maris College, Gzira GZR 1152, Malta \\ Correspondence: Dr. Adobi Jessica Timiyo, College of Business, The American University of Malta, Bormla \\ BML1013, Malta. Tel: 356-7776-8882. E-mail: jesikkaah@yahoo.com
}

Received: March 31, 2021

Accepted: May 15, $2021 \quad$ Online Published: June 4, 2021

doi:10.5539/hes.v11n3p10

URL: https://doi.org/10.5539/hes.v11n3p10

\begin{abstract}
Education is still a leeway towards achieving individual's personal growth as well as professional development. Further and Higher Education (FHE) are even more crucial in accelerating the achievement of these goals. Consequently, graduate students explore endless opportunities to enroll for postgraduate programs, hoping to gain financial independence, economic freedom, and improved standard of living after completion. Since graduate programs offer such tremendous career and life-changing opportunities, it is imperative to investigate if programs like the master's in business administration are still relevant in today's fast-moving business environment. This phenomenology study systematically utilizes underlying assumptions of research-based learning to assess a core aspect of universities' MBA curriculum, that is writing a dissertation. It examines the value added by dissertation to graduates' long-term career goals. Data for the study was obtained from fourteen MBA graduates through unstructured in-depth interviews. All the graduates currently work as full-time employees in their respective organisations, who were drawn from four main departments namely marketing, education, accounting and the IT industry. Our findings are thought provoking, yet compelling, in the sense that participants expressed mixed opinions concerning whether the dissertation prepared them for their current job roles. Most of them attributed their career successes to luck and hard work. Good communication and leadership skills also played major roles. Only few of them did acknowledge honing such skills while writing their dissertation during the research process. The implication of this research to stakeholders of higher education institutions, and policy makers, are also discussed.
\end{abstract}

Keywords: dissertation, employability, career development, research-based learning, MBA

\section{Introduction}

\subsection{Statement of the Problem}

Education facilitates individual productivity, which is often reflected in one's income level (Ashenfelter \& Rouse, 1998). Many see education as a door towards becoming successful professionally and personally as employees are likely to gain promotion with every additional degree they obtain. This is expected to increase their finances and ultimately lead to a better quality of life. Advanced graduation programs will likely enhance the knowledge and skills of individuals to be competent at work, in the same way that education is an important investment in human capital development. Education, generally, helps to boost countries' economic development agenda while at he same time enhancing peoples' work productivity (Janer et al., 2015). From an organization's point of view, most companies expect employees to work in teams, and often provide means for them to do so successfully. Partly so that employees can develop the much-needed interpersonal skills. Thus, it is not surprising to know that good communications and problem-solving are among the highly rated employability skills (Yorke \& Harvey, 2005) that employers require from candidates seeking employment. Many employers are dissatisfied with the skills acquired by graduate students (Landrum et al., 2010).

Mainstream research (Connor, 1995; Longworth \& Davies, 1996) suggest MBA graduates need more than just a degree to gain employment. In addition to degree qualifications, they need practical hands-on experience and competence to perform tasks at work. Even though the essence of professional courses like the MBA is to equip students with requisite skills needed for their promotion or career advancement (Azizah et al., 2012), there is a misfit between the graduate degree programs and graduates' employability skills (Cranmer, 2006). Thus, raising doubts about the curriculum of some postgraduate degree programs and how they are designed. Within the field 
of management, writing a dissertation is a key aspect of the Master's in Business Administration (MBA) programs even as it remains unclear how the dissertation experience, acquired by $21^{\text {st }}$ century graduates, is relevant to graduate career prospects. Studies (Bennis \& O'Toole, 2005) have shown that MBA does not provide sufficient knowledge relating to business, at best, it offers theoretical insights into the business world. Hence students struggle to perform in practical real-work situation of uncertainties and risks. They are not sure if research modules, as demonstrated through research-based learning, are relevant in helping them navigate challenges at work (Booth \& Harrington, 2003).

Research-Based Learning (RBL), according to Huber (2014), is a research process where students are assigned to an instructor who act as a facilitator, and whose responsibility is to guide them throughout the research process. This method of facilitating learning is a key requirement of most graduate programs (Tight, 2016). Part of the research process requires students to identify a research problem, carefully design, and execute the research. Even though students are guided by instructors during the process, they are the major players for spending significant amount of time reading journals, collecting, and analysing the research data. Since research requires the collaboration of students and supervisors, identifying specific research-related skills in students during their extensive research activities is expedient. Especially, if such skills are expected to make meaningful contributions in advancing graduates' career goals.

\subsection{Significance of the Problem}

Despite its best intention of fostering student-centred learning (Soltano et al., 2016), research-based learning has certain limitations. One of such limitations is the absence of a major practicable theoretical approach towards conducting research (Brew, 2010; Brew \& Saunders, 2020). Van der Meulen (2011) argues that engaging students in prolong research activities might isolate them from taking part in other extra curricular and leisure activities. Simply, because research is usually conducted by academics and research professionals (Dorfman \& Lipscomb, 2005; Topping \& Hoffman, 2002). A crucial aspect of the research process is analysing the data, and this often requires the use of statistical tools, especially for students that adopt quantitative deductive research approach. This might be challenging for students who have difficulty coping with mathematics-related courses, hence research might pose a great hurdle for these category of students (Winicki, 2006). The dissertation, which is outcome of the research process, is mostly informative since it is expected to add to existing body of knowledge in a specific field of study. However, students who choose careers in business most probably will not engage in any sort of research activity after graduation (Hoidn, 2017). While our research is not an attempt to exaggerate the rigours of conducting research activities, we believe there is an urgent need to prepare and equip business students. Particularly, with life-long skills that will enable them cope with twenty-first century workplace challenges (Mohammad, 2015). Since employers would likely recruit candidates with good analytical and problem-solving skills, MBA graduates have great prospects working for firms that are strongly rooted in business and management principles (Buenviaje et al., 2016).

This means that employability is seen as a vital aspect of postgraduate degree programs that universities ought to consider when designing the MBA curriculum (Morley, 2001). There have been calls for universities to incorporate work-related skills in degree programs due to their strategic role in enhancing graduates' chances of being employed (Macatangay, 2013). Unfortunately, despite pedagogical advancements in education, there is lack of proactive engagement in research-based learning within the field of business. Such approach even if it exists, is limited as revealed by the absence of extant literature addressing the subject matter. The absence of sufficient literature also tends to undermine the role of employers in this discourse. Employers are the ones that determine the particular skill sets that job-seeking candidates should possess, consequently, the decision to hire MBA graduates lies within them (Aquino et al., 2015). This means MBA students must be competent enough to effectively performt key functional tasks in business such as marketing, operations, finance, and human resources management (Meñez, 2014). Besides, these skills are instrumental to candidates' success during the selection process (Buenviaje et al., 2016). Incidentally, business educators are increasingly adopting customer-centric approach, through professionalism and evidence-based research, to address needs of their stakeholders (Knowles \& Hensher, 2005). Thus, the need to do more in preparing graduate students for work cannot be overemphasized (Dean \& Clements, 2010).

\subsection{Aim and Objectives of the Research}

This qualitative study aims to explore the views of MBA graduates whether they found their dissertation experience helpful in any way possible. Particularly with respect to their ability to find a job and effectively perform within their respective roles. In the past, studies like these had huge implications to stakeholders of educational institutions, including students, employers, and policy makers (Kooij et al., 2011), the same is true 
for this research. To achieve the research aim, we propose the following three objectives:

- To determine if MBA graduates acquired any specific skills from writing dissertations

- If yes, then to know if the skills they acquired helped them to find a job

- To determine if the skills enhanced their career advancement and job performance

\section{Literature Review}

The next section of the paper addresses extant literature on research-based learning and employability skills relevant to graduates that are searching for jobs.

\subsection{Research-Based Learning}

Research-Based Learning (RBL) fosters scientific knowledge and treats the entire learning process as an ongoing quest for knowledge creation. It is anathema to the traditional teacher-to-student based methods of learning for encouraging education service providers to adopt lifelong approach to learning. By actively taking part in research activities so as to continuously gain new perspectives (Blume et al., 2015; Brew \& Saunders, 2020; Prahmana \& Kusumah, 2017), RBL urges students to do more of self-study. Its underlying assumption is that students are likely to acquire and develop certain problem-solving skills as they learn by doing practical research activities (Prahmana \& Kusumah, 2017). However, some have argued that research-based learning is more suitable for students taking courses in STEM (Science, Technology, Engineering, and Mathematics), than those in social sciences (Taraban \& Logue, 2012). While this may offer some sort of consolation to social science students, majority of students, regardless of their discipline, view research as a daunting task. Partly, because the entire research process demands high level of self-study from students, self-motivation, and ability to navigate change (John \& Creighton, 2011), especially as students become demotivated.

Demotivation is quite common among research students struggling to create knowledge with little or no experience (Wessels et al., 2018). They struggle with how to identify a researchable topic and deciding type of research methodology to adopt. Consequently, many students end up repeating the same idea over and over when writing up the final report (Qasem \& Zayid, 2019). Graduate students consider research modules that form part of postgraduate academic course content, usually in form of writing a dissertation, irrelevant and rarely inappropriate in addressing real life situations (Booth \& Harrington, 2003). The dissertation, according to COBUILD Advanced English dictionary, is 'a long formal piece of writing on a particular subject, especially for a university degree or a written thesis, often based on original research, usually required for a higher degree or a formal degree'. It is a major part of an MBA degree program where students are expected to submit original research work in an extensive written discourse, irrespective of whether students possess the right skills and knowledge to write a dissertation. Though extant literature is quite clear concerning how to conduct research, the same is not true regarding how to teach research modules in schools.

\subsection{Higher Education Stakeholders}

Stakeholders of higher education institutions including students, employers, government, and faculty members (Kooij et al., 2011) all play a role in shaping graduates' career developmental agenda. However, each often tend to pursue separate goals. For students, being work ready with sufficient transferable skills by the time they graduate from their studies is of strategic importance to them (Mohammad, 2015). Before enrolling for an MBA program, most students envisage this as opportunity to acquire new skills like communication and problem-solving needed for them to excel at work. Good communication is crucial for candidates desiring to work in diverse multicultural organizations (Buenviaje et al., 2016). Unfortunately, tuition fees for graduate programs are quite high, thus forcing most students to work and study at the same time to be able to pay the fees (Gill, 2016), but some find it quite challenging. Demand from work can pressure students to spend twice the number of time needed to study and complete a postgraduate degree program (Manthei \& Gilmore, 2005). Work is necessary for students to gain experience over time. The tendency for students to combine work and study has often been criticized. Some have argued that students can acquire relevant work experience when doing internships. Nevertheless, internships offer only basic knowledge that is considered inadequate for students to perform certain kinds of tasks (O’Neill, 2010),

Employers, on the hand, prefer employees possessing hands-on skills, particularly transferable skills like oral communication, analytical skills, self-awareness, and interpersonal skills (Connor, 1995; Warn \& Tranter, 2001). In addition to obtaining a postgraduate degree in business, employers would like graduates who are capable of handling complex information and situations (Knight \& Yorke, 2002). Traditional firms did require employees to perform mundane tasks. But this has since changed right after the industrial revolution. Nowadays, firms are more interested in creating working environments that allow innovation and creativity thrive. Likewise, 
employment decisions in some firms are equally defined by innovative laws and policies. On the part of government, the European employment summit of 1997, held in Luxembourg, places employability skills as deciding factors for employing a candidate. Employability therefore, is the ability for employees to successfully integrate into the work environment (Bollérot, 2001). The underlying assumption is that a person's skills developed during a particular period (e.g., education) will be useful when transferred into another context (i.e., work).

Unfortunately, most MBA programs are not designed to address such issues (Bennis \& O’Toole, 2005; Pfeffer \& Fong, 2002). Moreover, some researchers (Boden \& Nedeva, 2010; Smith \& Bath, 2006) feel that most degree programs and curriculum contain too much theoretical knowledge. Lastly, faculty members desire to work in an environment that support active research and teaching, even though they sometimes struggle to successfully balance these activities (Gill, 2011).

\section{Methods}

This is a qualitative research that uses in-depth interviews, and unstructured interview protocol, to gain understanding of the personal experiences of graduates of MBA program. Thus, the third section of the paper highlights the research design used in the study, including the sampling procedure, data collection, and data analysis methods. It also provides a general description of the participants, who took part in the study.

\subsection{Research Design}

Being a qualitative study means it is imperative to utilise corresponding qualitative research designs, hence we adopted the phenomenology research design to inductively obtained relevant information from participants who volunteered to participate in the study. As common with studies of this type, the inductive approach relies heavily on the use of in-depth interviews that allows researchers to obtain pertinent information needed to address the research objectives. A typical phenomenology study requires both researchers and participants to collaborate for the purpose of creating knowledge (Lester, 1999). However, it is up to researchers to determine the data analysis procedures to be used; likewise, the interpretations and conclusions drawn from the findings of our study. Furthermore, we rely on fundamental assumptions stating that research design "is not limited to an approach to knowing, it is rather an intellectual engagement in interpretations and meaning making that is used to understand the lived world of human beings at a conscious level" (Qutoshi, 2018, p. 215).

\subsection{Sampling Procedures}

We adopted purposeful and snowball (or chain referral) sampling methods in this study. Both methods are widely used in qualitative studies. Purposeful sampling methods allowed us to systematically collect data, particularly when recruiting participants with the expertise or knowledge of the subject matter becomes a vital aspect of the research (Creswell \& Clark, 2017a). Snowball sampling, on the other hand, was also adopted as we asked participants to help recruit other participants who might be interested to take part in our study. Concerning the sample size for our study, so far, only few studies have addressed the appropriate sample size for qualitative studies (Jones, 2002; Onwuegbuzie \& Leech (2004). Results from these studies suggest that the right sample size for qualitative studies should be between five to fifteen participants (Dworkin, 2012). In view of this, the sample size for our study consists of fourteen MBA graduates. While the analysis of the study's data is based on the students' views, the interpretations are based on our own understanding of the experiences narrated by the students themselves. Hence, we are not making any absolute claims, neither do we intend to generalize our findings to include broad spectrum of the population of MBA graduates.

\subsubsection{Recruitment of Participants}

Therefore, we recruited the fourteen participants who agreed to participate in this research. First, we approached an alumnus of our university that was willing to participate in the study. As soon as he indicated interest to take part, a consent letter was emailed to him. The letter clearly highlights the aim and objectives of our study. It also outlines what obligations are required from him. Second, we then booked an appointment to have an audio recorded interview with him, based on his availability. After the interview, we asked him to suggest others that might be willing to participate in the study. He obliged to our request, and this was how we employed chain referral to recruit more and more participants for the study. Even though, chain referral was employed, we were careful to recruit the study's participants in accordance with Creswell and Clark (2017) guidelines for recruiting participants for qualitative studies. By making sure only participants with previous experience of writing dissertation during MBA were recruited to take part in the study. The fourteen participants that form the sample size, demonstrated having knowledge of the study matter, hence meet the criteria to be included in the study. Since the study requires individuals with specific characteristics, a request to potential participants was posted on various 
social media platforms, including Facebook, Instagram, and Twitter. All fourteen former MBA students who took part in the study now work as full-time employees in their respective organizations. Among them were four marketing executives, five education officers, and two accounting assistants, one marketing assistant, and two IT managers. Their demographic information is presented below (see Table 1).

Table 1. Demographics of the participants

\begin{tabular}{ll}
\hline Job Sector/Role & Experience (Years) \\
\hline Four marketing executives & Six - nine \\
Five education & Ten - fifteen \\
Two accounting & Sixteen \\
One marketing assistant & Twenty - five \\
Two IT managers & Zero - five \\
\hline
\end{tabular}

\subsection{Data Collection and Analysis Procedures}

An unstructured interview guide was used to obtain data for the study through in-depth interviews, done on one-to-one basis. During the interviews, which lasted on the average for forty-five minutes, participants openly and freely shared their educational backgrounds as well as employment history. They also responded to the issues raised in the study. Some of the questions addressed by the participants include:

- Did the MBA course content prepare you to write your dissertation?

- Can you please share your MBA research project experience with us?

- Were there any specific skills you acquired while writing your dissertation? (Kindly name a few of them please).

- Did the skills help you to find a job?

- Are they useful in your job performance now?

- Are they relevant in your career growth and development?

The data was later analysed thematically. Thematic analysis is appropriate for studies, where using research questions forms an integral part of the study. However, the steps we adopted during the thematic analysis are consistent with those proposed by Nowell et al. (2017), which include "data familiarization, generating initial codes, identifying themes, reviewing themes, defining themes, and writing a report" (Nowell et al., 2017).

\subsubsection{Coding the Data}

We utilized gerunds to categorise and build relevant themes during the data coding process. Our initial coding resulted in six categories, which were later reduced to manageable size. Subsequent categorisation of the coded data presents three main themes named as acquiring skills, securing job, and enhancing career (see Figure 1). Each theme is presented accordingly in the next sections of the article. Furthermore, we paid less emphasis on participants' gender since we were not concerned with obtaining gender-specific information from the participants. Thus, we were careful not to impose any preconceived biases as we engaged with them because gender debates are often seen as very controversial. This is the reason we excluded participants' gender from the biodata (i.e., participants' demographic information).

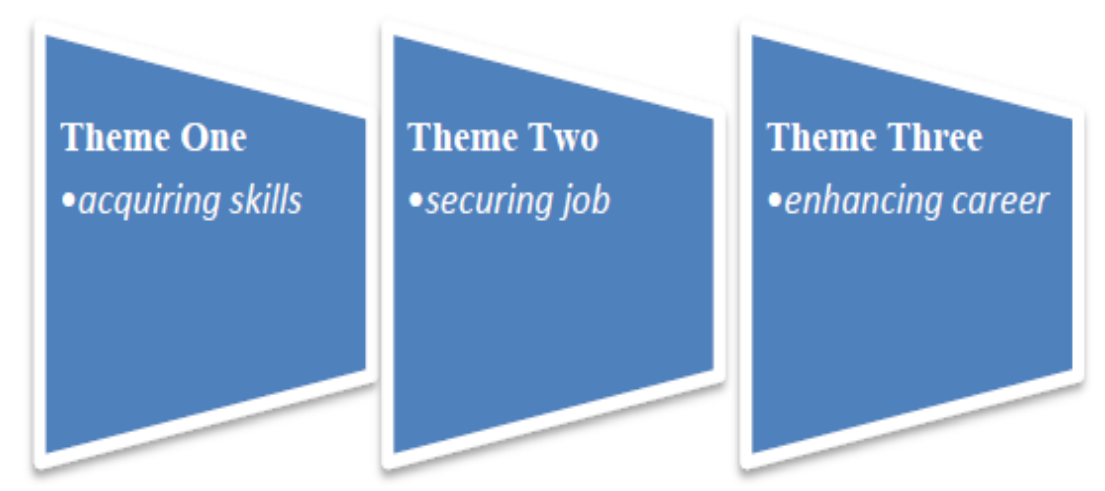

Figure 1. Relevant themes 


\subsubsection{Theme One (Acquiring Skills)}

The first theme we identified, while coding the data, is acquiring skills, which has been presented in Table 2 .

Table 2. Interview transcripts on acquiring skills

.. how to do how to fix up a meeting how to break the ice, how should I make him to come to the meeting and then break the ice between us.

Questionnaire preparation...the communication skills...I also learned very good interpersonal skill, I improved on that with my MBA, with my presentation skills...PowerPoint skills ...to know how to understand the human rather

If a person is given a training, kind of, or you know information regarding any kind of you know issue... probably the efficiency of way will be higher

I learned a lot ...how to communicate with the customers and learned how to develop my skills to get the business

....anything about skills acquisition. I think mine bachelor dissertation was almost the same...So I am not sure I have an extra ordinary skill for my dissertation from beginning to end. so probably maybe I polish the skills that I had, but not necessarily really acquiring new skills

How to write? How to write something would affect in very few words? Academic writing, statistical analysis, how to structure a research project, can help in the decision-making process as well.

Sampling, how effectively we can utilise the distribution network

Acquiring skills describes participants' views on ways that research-based learning enhances their job roles. This theme addresses the first objective of the study, which is determine if MBA graduates gained any skills from writing dissertations. Excerpts from participants' interview transcripts are presented in Table 2. Some of the interviews were transcribed verbatim, hence captures repetitive words and exclamations. The data suggests even though some of the participants were working already, prior to enrolment into the MBA program, engaging in research activity (via dissertation) seemed to have benefited them tremendously. Thus, they acknowledged gaining specific skills due to their research experience while writing the dissertation.

\subsubsection{Theme Two (Securing Job)}

The second theme we identified from the data was securing job. Excerpts from participants' interview transcripts showing these statements are presented in Table 3 .

Table 3. Interview transcripts on securing job

...Securing my job! Not very much...maybe I learned how to know how to show off myself such that I will be picked up by the company.

...Of course, it has, because initially, I when I finished my MBA, of course, I took up my current job only which was into human resource and then I also worked into recruitment.

...Initially as I said, I did not get the job, which I was looking into might be okay...I don't have that much of knowledge, I don't have contacts in the market... a person who has got experience will be much sooner like by any people...So slowly I have developed myself and I self I myself trained to that kind of an approach.

Yeah. Hundred percent because I did my project in marketing this thing. So presently I'm doing the same thing.

...So it totally depends on what the person want to specialize in, or the type of job the person is actually seeking for.

...Absolutely. Yes...employers look at experience and experiences somebody has ...another was what value can they read kind of person really bring to the table as well?

...Yeah, definitely...first they have to sample test the product...you know same thing now I am into financial industry...So, effectively you utilise those distribution channels.

The theme securing job describes how research skills, gained through the process of writing dissertation, was instrumental to the participants ability to find and secure a job. Data from this theme addresses the second objective of the study, which is to know if the skills they acquired helped them to find. In other words, were the skills instrumental to graduates ability to find a job? Thus, securing job theme enhanced our understanding of the value added by dissertation towards increasing graduates' employability chances. It reveals the strategic relationship between dissertation and employability. Thus, Table 3 contains excerpts of interview transcripts from the research participants, expressed in their own words, as they reflect on their employment experiences after graduating from the MBA program. 


\subsubsection{Theme Three (Enhancing Career)}

Finally, we proceeded towards addressing the third objective of the study, which is determine if the skills enhanced their career advancement and job performance. The theme we identified from the data was enhancing career, which explores participants' views regarding career advancements and pursuing lifelong goals. Data used in addressing this objective is presented in Table 4.

Table 4. Interview transcripts on enhancing career

No, I don't think so, because my dissertation was on social media marketing and its influence on the salability of the products, but presently I am dealing with different kinds of roles, selling skills is basic thing that you have to learn from any point of either dissertation or MBA curriculum or anything. That's the first thing. Secondly, communication.

I think...if I say learning never stops, yeah, it's not that only MBA has taught me...I think apart from all this, my own values or you know, it has helped me because the higher you get educated or you learn a lot, you learn many things and learning is not only from the textbook, and it is not.

Yeah, obviously, I have learned presentation kind of thing, when you have to present a product or a laptop or a presentation, PowerPoint presentation e.g., are they in eye contact with me? Am I on to the same line or not with them? I need to check the understanding of the person when I'm giving a presentation...Yeah, I have learned it from my dissertation.

Yes, I think I did two accounting courses, and I would say it's actually enlightened me

Yeah, in terms of transferable skills, not just because of soft skills to help make better decisions as well.

Yeah... in any company if you know the process for example, for any employer a vintage employee is an asset...will be time saving for the employer and employer and we'll be able to maximise the results.

Subsequent coding of the data resulted in the formulation of the third theme for this study, which is named enhancing career. The data revealed that participants expressed mixed views regarding whether graduates' dissertation experience have long term benefits towards actualizing their future career ambitions. While some participants believe their dissertation experience helped them to refine new skills, others felt it only honed existing skills they had before enrolling for a MBA program. Excerpts from the participants, as contained in the interview transcripts, are presented in Table 4.

\section{Discussion of Findings}

The theme acquiring skills was developed after participants confirmed they acquired certain skills through conducting research as they wrote their dissertations. Most of them performed live projects using either in small or big organisations as case studies, hence mentioned positive outcomes (skills) about their dissertations. Undoubtedly, this suggests that the MBA program is crucial in honing graduates' competence and skills that they used in performing their jobs. Some of the skills we identified from our study include communication, interpersonal, and presentation skills, which participants find very useful in their current job roles. Our findings corroborate previous research like Meñez (2014) that suggests MBA graduates can successfully work within any functional areas of business, including marketing, human resources management, finance, and operations. Apart from effectively engaging in strategic decision-making process, researchers (Macatangay, 2013) often opined that postgraduate degrees should help develop certain skills like leadership and problem-sovling skills among graduate students. Other scholars (Wessels et al., 2018) supporting this stance added that to successful manage a business organization, managers need to have a considerable level of competency in analytical and strategic thinking. In the same vein, participants in this study said engaging in research activities (during dissertations), prepared them to be able to think critically when handling issues at work.

Despite its numerous advantages, there is an absence of empirical evidence examining the effectiveness of research-based learning in the social sciences. Even if such evidence exists, it is relatively scarce (Wessels et al., 2018). Our findings suggest, participants weighed into the decision to pursue two contradictory objectives. Either they were willing to gain experience by working continuously or leaving work at some point for study. Those who argue that the dissertation experience did not contribute much to their career goals seemed to place emphasis on gaining work experience, rather than going for further studies. Below is an excerpt from the interview transcript of one of the participants:

Initially as I said, I did not get the job, which I was looking into might be okay. I don't have that much of knowledge; I don't have contacts in the market. A person who has got experience will be much sooner liked by people. So slowly I have developed myself and I trained myself to that kind of an approach 
The second theme, securing job, was identified to know if dissertation helped participants to secure a job, to which most expressed mixed feelings. A careful analysis of the data reveals some participants agreed writing a dissertation equipped them to be gainfully employed, but others disagreed. Thus, our finding supports previous research (Buenviaje et al., 2016) that dissertation honed graduates' communication skills, which later became quite relevant to their current job roles. Good communication skills prepared them to face language and communications barriers within the international arena. This is because MBA programs are basically designed to help graduates acquire basic managerial skills like teamwork and leadership skills as confirmed by previous research (Tarso Resende, 2011). A study by Dean and Clements (2010) supports this stance that MBA programs are helpful in addressing demands and expectations of the modern workplace. Our study's participants equally support this view stating that skills they acquired were particularly helpful to them in addressing real-life business situations. In some instances, such skills enabled them to fit into their job roles almost immediately. Though some participants attributed their career success to luck, hard work, and personal values, hence do not think research skills were instrumental to their career success.

This is because employees are expected to perform daily routine tasks, they can possibly learn on-the-job, without necessarily requiring or relying on a degree to do so. With respect to the third theme - enhancing career, few participants agreed the experience they got writing dissertation prepared then for future career prospects. However, research suggests (Azizah et al., 2012) that graduates' career success, defined by high ranking positions, salaries, and promotions, is a matter of attending prestigious business schools. Furthermore, in support of an early study (Bollérot, 2001), our study's participants raised the issue of adaptability as key factor for achieving career goals. In other words, employees' ability to integrate into the work environment is crucial to their effective job performance. Dissertations undoubtedly refines graduates' employability skills, but its role in career development is insignificant.

\section{Conclusion}

This study sheds light on the value added by writing dissertation to graduate career success. Hence, it has implications for both students and employers. Students can rely on findings from the study to prepare themselves for job interviews throughout a firm's recruitment process. Since the research is based on the perspectives of MBA students researching skills, students who are research-oriented can benefit from the study. Employers, on the other hand, can possibly liaise with higher education institutions and contribute towards designing market-specific graduate program course curriculums. Though some may not see training or developing new employees as a wise investment decision (Bennis \& O'Toole, 2005). In conclusion, we believe writing dissertation via research-based learning is beneficial to MBA graduates. They will benefit even more by doing the dissertation using their current workplace as cases studies, and in some instances with the support of line managers. Since our study did not incorporate views of employers, future research area could examine their perspective. We also recommend using quantitative approach to replicate the present study by examining the extent that writing a dissertation impacts graduates' employability chances.

\section{Acknowledgments}

We hereby confirm that we have not received any grants nor financial support from any bodies throughout the entire research process. This means there are no relevant competing interests to disclose. We would like to thank colleagues and staff of our respective institutions for being supportive throughout the research process, providing prompt and invaluable feedback regarding the paper. Also, we thank all participants, who took time off work to participate in the study. We could not have completed the research without their willingness and readiness to narrate and share their experiences with us.

\section{Reference}

Aquino, A. B., Punongbayan, E. J., Macalaguim, L. P., Bauyon, S. M., Rodriguez Jr, R. A., \& Quizon, G. R. (2015). Teacher education graduate tracer study from 2010 to 2014 in one state university in Batangas, Philippines. Asia Pacific Journal of Multidisciplinary Research, 3(5), 45-50.

Ashenfelter, O., \& Rouse, C. (1998). Income, schooling, and ability: Evidence from a new sample of identical twins. The Quarterly Journal of Economics, 113(1), 253-284. https://doi.org/10.1162/003355398555577

Azizah, D., Mokhtar, S. S. M., \& Pangil, F. (2012). The influence of educational-factor capital on the tangible career outcomes of MBA graduates. International Journal of Business and Management Studies, 4(1), 31-43.

Bennis, W. G., \& O’Toole, J. (2005). How business schools have lost their way. Harvard Business Review, 83(5), 96-104. 
Blume, S., Madanchi, N., Böhme, S., Posselt, G., Thiede, S., \& Herrmann, C. (2015). Die Lernfabrik-Research-based learning for sustainable production engineering. Procedia CIRP, 32, 126-131. https://doi.org/10.1016/j.procir.2015.02.113

Boden, R., \& Nedeva, M. (2010). Employing discourse: Universities and graduate 'employability'. Journal of Education Policy, 25(1), 37-54. https://doi.org/10.1080/02680930903349489

Bollérot, P. (2001). Two actors in employability: The employer and the worker. In P. Weinert (Ed.), Employability-From Theory to Practice (pp. 51-90). Transaction Publisher.

Booth, C., \& Harrington, J. (2003). Research methods modules and undergraduate business research: An investigation. International Journal of Management Education, 3(3), 9-31. https://doi.org/10.3794/ijme.33.78

Brew, A. (2010). Imperatives and challenges in integrating teaching and research. Higher Education Research \& Development, 29(2), 139-150. https://doi.org/10.1080/07294360903552451

Brew, A., \& Saunders, C. (2020). Making sense of research-based learning in teacher education. Teaching and Teacher Education, 87, 102935. https://doi.org/10.1016/j.tate.2019.102935

Buenviaje, M. G., Encio, H. A., Refozar, R. F., Anuran, A., Camello, N. C., \& Laguador, J. M. (2016). Employability and Skills of MBA Graduates from Literature Review as Input to Student Development Program. Journal of Research in Business and Management Volume, 4(5), 16-21.

Connor, H. (1995). Graduates: Shortage or glut? Research Report-Policy Studies Institute, 33-44. https://doi.org/10.1016/0378-4290(95)90078-0

Cranmer, S. (2006). Enhancing graduate employability: Best intentions and mixed outcomes. Studies in Higher Education, 31(2), 169-184. https://doi.org/10.1080/03075070600572041

Creswell, J. W., \& Clark, V. L. P. (2017a). Designing and conducting mixed methods research. Sage publications.

Creswell, J. W., \& Clark, V. L. P. (2017b). Designing and conducting mixed methods research. Sage publications.

Dean, B. A., \& Clements, M. D. (2010). Pathway for student self-development: A learning orientated internship approach. Australian Journal of Adult Learning, 50(2), 287-307.

Dorfman, J., \& Lipscomb, S. D. (2005). Graduate music students' attitudes toward research. Journal of Music Teacher Education, 15(1), 31-42. https://doi.org/10.1177/10570837050150010106

Gill, R. (2016). Bridging the knowledge gap between study and professional practice: An Australian case example. International Journal of Academic Research in Progressive Education and Development, 15(1), 20-34. https://doi.org/10.6007/IJARPED/v5-i1/2010

Gill, R. (2011). Theory and practice of leadership. SAGE Publications Ltd.

Hoidn, S. (2017). Learning and teaching (about) research methods in graduate management education. Academy of Management, 2017(1), 17300. https://doi.org/10.5465/AMBPP.2017.17300abstract

Huber, L. (2014). Forschungsbasiertes, Forschungsorientiertes, Forschendes Lernen: Alles dasselbe? Ein Plädoyer für eine Verständigung über Begriffe und Unterscheidungen im Feld forschungsnahen Lehrens und Lernens. Das Hochschulwesen, 62(1), 2.

Janer, S. S., Deri, R. A., Dio, R. V., Marbella, F. D., \& Ricafort, J. D. (2015). Factors on enhancing competitive edge and attributes of graduates as inputs to the development of teacher education enhancement program (TEEP). Asia Pacific Journal of Multidisciplinary Research, 3(4), 25-33.

John, J., \& Creighton, J. (2011). Researcher development: The impact of undergraduate research opportunity programmes on students in the UK. Studies in Higher Education, 36(7), 781-797. https://doi.org/10.1080/03075071003777708

Knight, P. T., \& Yorke, M. (2002). Employability through the curriculum. Tertiary Education and Management, 8(4), 261-276. https://doi.org/10.1080/13583883.2002.9967084

Knowles, L., \& Hensher, D. (2005). The postgraduate business curriculum: The frontline in the war between professionalism and academic irrelevance. The International Journal of Management Education, 4(3), 31-39. https://doi.org/10.3794/ijme.43.94

Kooij, D., Paauwe, J., Sanders, K., Scurry, T., \& Blenkinsopp, J. (2011). Under-employment among recent 
graduates: A review of the literature. Personnel Review.

Landrum, R. E., Hettich, P. I., \& Wilner, A. (2010). Alumni perceptions of workforce readiness. Teaching of Psychology, 37(2), 97-106. https://doi.org/10.1080/00986281003626912

Lester, S. (1999). An introduction to phenomenological research.

Longworth, N., \& Davies, W. K. (1996). Lifelong Learning: New Vision, New Implications, New Roles for People, Organizations, Nations and Communities in the 21 st Century. ERIC.

Macatangay, L. (2013). Tracer study of BSCS graduates of lyceum of the philippines university from 2004-2009. Academic Research International, 4(5), 361.

Manthei, R. J., \& Gilmore, A. (2005). The effect of paid employment on university students' lives. Education+ Training. https://doi.org/10.1108/00400910510592248

Meñez, N. (2014). Tracer study of the Masters in Business Administration (MBA) graduates from 2008-2012. Asia Pacific Journal of Education, Arts and Sciences, 1(1), 14-18.

Mohammad, A. (2015). Experimental methods of teaching business studies: Practical approaches beyond lecturing. International Journal of Core Engineering \& Management, 1(12), 59-73.

Morley, L. (2001). Producing new workers: Quality, equality and employability in higher education. Quality in Higher Education, 7(2), 131-138. https://doi.org/10.1080/13538320120060024

Nowell, L. S., Norris, J. M., White, D. E., \& Moules, N. J. (2017). Thematic analysis: Striving to meet the trustworthiness criteria. International Journal of Qualitative Methods, 16(1), 1609406917733847. https://doi.org/10.1177/1609406917733847

O'Neill, N. (2010). Internships as a high-impact practice: Some reflections on quality. Peer Review, 12(4), 4-8.

Pfeffer, J., \& Fong, C. T. (2002). The end of business schools? Less success than meets the eye. Academy of Management Learning \& Education, 1(1), 78-95. https://doi.org/10.5465/amle.2002.7373679

Prahmana, R. C. I., \& Kusumah, Y. S. (2017). Didactic trajectory of research in mathematics education using research-based learning. Journal of Physics: Conference Series, 893(1), 012001. https://doi.org/10.1088/1742-6596/893/1/012001

Qasem, F. A. A., \& Zayid, E. I. M. (2019). The challenges and problems faced by students in the early stage of writing research projects in L2, University of Bisha, Saudi Arabia. European Journal of Special Education Research.

Qutoshi, S. B. (2018). Phenomenology: A philosophy and method of inquiry. Journal of Education and Educational Development, 5(1), 215-222. https://doi.org/10.22555/joeed.v5i1.2154

Smith, C., \& Bath, D. (2006). The role of the learning community in the development of discipline knowledge and generic graduate outcomes. Higher Education, 51(2), 259-286. https://doi.org/10.1007/s10734-004-6389-2

Soltano, E., Meyer, S., \& Larrivee, L. (2016). Involving Students in Interdisciplinary Faculty Research Teams: Benefits and Limitations. Currents in Teaching \& Learning, 7(2), 38-45.

Taraban, R., \& Logue, E. (2012). Academic factors that affect undergraduate research experiences. Journal of Educational Psychology, 104(2), 499. https://doi.org/10.1037/a0026851

Tarso Resende, P. (2011). América Latina: Formando talentos globales. MBA International Business, 12(49), 40-42.

Tight, M. (2016). Examining the research/teaching nexus. European Journal of Higher Education, 6(4), 293-311. https://doi.org/10.1080/21568235.2016.1224674

Topping, D. H., \& Hoffman, S. J. (2002). Helping Teachers Become Teacher-Researchers. Journal of Reading Education, 27(3), 20-29.

Van der Meulen, E. (2011). Participatory and action-oriented dissertations: The challenges and importance of community-engaged graduate research. Qualitative Report, 16(5), 1291-1303.

Warn, J., \& Tranter, P. (2001). Measuring quality in higher education: A competency approach. Quality in Higher Education, 7(3), 191-198. https://doi.org/10.1080/13538320120098078

Wessels, I., Rueß, J., Jenßen, L., Gess, C., \& Deicke, W. (2018). Beyond cognition: Experts' views on affective-motivational research dispositions in the social sciences. Frontiers in Psychology, 9, 1300. 
https://doi.org/10.3389/fpsyg.2018.01300

Winicki, B. (2006). Reading teachers and research: From consumers to evaluators to producers. Journal of Reading Education, 31(3), 21.

Yorke, M., \& Harvey, L. (2005). Graduate attributes and their development. New Directions for Institutional Research, 2005(128), 41-58. https://doi.org/10.1002/ir.162

\section{Copyrights}

Copyright for this article is retained by the author(s), with first publication rights granted to the journal. This is an open-access article distributed under the terms and conditions of the Creative Commons Attribution license (http://creativecommons.org/licenses/by/4.0/). 